\title{
SCIENTOMETRIC ANALYSIS OF LEUKEMIA RESEARCH OUTPUT DURING 2010-2019
}

\author{
K. Ayyanar , M. Nagaiah ${ }^{2}$, K. Thiruppathi ${ }^{3}$ \\ ${ }^{1}$ Research Scholar, Department of Library and Information Science, \\ Alagappa University, Tamil Nadu, \\ Email-lavanyamphil92@gmail.com \\ ${ }^{2}$ Research Scholar, Department of Library and Information Science, \\ AlagappaUniversity, TamilNadu, \\ Email-gaffaram@gmail.com \\ Orcid id - 0000-0003-0500-8119 \\ ${ }^{3}$ Deputy Librarian, Department of Library and \\ Information Science, Alagappa University, Tamil Nadu, \\ Email-libkishore@yahoo.com \\ orcid id-0000-0001-7694-4807
}

\section{Manuscript Info}

\section{Manuscript History}

Received: 03 January 2021

Final Accepted: 22 February 2021

Published: 10 March 2021

Online Published: April 2021

DOI: http://dx.doi.org/10.35337/EIJLITR.2021.1402

(C) K. Ayyanar, M. Nagaiah , K. Thiruppathi The Author. This is an open access article under the terms of the Creative Commons Attribution License 4.0, which allows use, distribution and reproduction in any medium, provided the original work is properly cited.

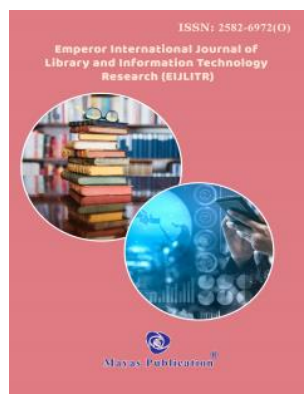

\section{Abstract}

This assessment destroys the assessment yield of Leukemia Research all through the planet. The assessment period covers the years from 2010 to 2019. A measure of 6512 data were essentially assembled from the catch of science educational combinations and subject to data inspected by using Histcite programming. MS Excel 2010 and Vos watcher was used explicit and alliance portrayal. Assessment had been done to see the event of massive data research yield at the general level. An amount of 6512 records were assembled from the Leukemia Research data base for the evaluation through glancing through the watchword Leukemia 1480(22.73\%), and thusly the enunciations being Cancer. The Author-wise scattering of the development showed that the Pui $\mathrm{CH}$ consolidated the focal situation with courses $41(0.63 \%)$ and Gale RP is inside the second condition with $39(0.59 \%)$ followed by Lazarus HW, Saber W, and others. $\mathrm{Li} \mathrm{J}$ fused the last circumstance with 30 arrangements $(0.46 \%)$. The year-wise movement of records in Leukemia Research uncovered that the year 2017 and 2018 fused the key position and as such the yield was extended $(11.61 \%)$ appeared unmistakably as indicated by 2010 and 2019. Examination suitability in Leukemia research is making. 
Key Words: Scientometric, Leukemia Research, Research Output, the catch of Science, cause arrangement, level of empowered exertion, Relative Growth Rate and Doubling Time.

\section{INTRODUCTION}

Appraisal of cytogenetic deviations adds quite far, hazard system, and supposition of the various leukemias and lymphomas, also on the appreciation of their science 1.Chronic myelomonocytic leukemia was entwined into the FAB (French - American - British) party of myelodysplastic conditions thinking about how dysplastic changes are consistently found in blood and bone marrow cells of patients with this disorder2. Was reliably a to some degree questionable sort of MDS. Notwithstanding the way that CMML can present like RAEB (unmanageable whiteness with wealth impacts) and should be discernable just by the presence of monocytosis $(41000 \mathrm{ml})$ within the blood, some clinical characteristics contrast from the "standard thing" presentation of MDS. Around 40 - half of CMML patients have splenomegaly what's more hepatomegaly 3,4 .

Barely any clinicians would separate that astounding, completely concur is crucial for the great quick of clinical danger research 5, 6. Decidedly less plan, coincidentally, goes with endeavors to portray "outstanding" and "totally prepared." Significant sales stay about the best way to deal with oversee give the proper degree of data to oldsters with different establishments and wish to help meet-and not bewilder - their decision, and the best way to deal with oversee gently engineer the clinical crucial to recover kids with the consistent drive to review them. Psychologic, social, and various issues confuse the picture: watchmen and clinicians accomplice round the subject of clinical foundations amidst tremendous vigorous pressing component 7.complex social and social questions 8 .

In 1928 Delore and Borgomano portrayed the focal occasion of "benzene leukemia," remarkable leukemia in a subject matter expert so overwhelmingly familiar with benzene that none of his fellow experts could stand two months without becoming ill. Not long after this first portrayal, various cases of leukemia credited to benzene were spread 9. In 1932, Lignac gave $0.001 \mathrm{ml}$ benzene in olive oil one small step at a time to 54 white mice more than 17-21 weeks and winning concerning passing on six leukemias and two entering a leukemia clympho blastomas, at any rate no occasions of leukemia made among 1465 mice taken as controls. Coming about tries to raise leukemia by ingraining research focus animals with benzene gave problematic results since occasions of leukemia similarly made inside the control animals almost to a hazy degree 10 .

\section{REVIEW OF LITERATURE}

Jeyshankar and Babu (2013)11analysed the diverse scientometric configuration like root plan, sorts of circulations, level of participation, association's responsibility, most productivity journal, and tracked down that the most limit 79.67 per The segment of dissemination was given by a couple of scholars, out of an aggregate of 2120 appropriations, 1524 conveyances were journaled articles type papers. (1987-1991) The most awesome 0.96-degree association was recorded during the time period. Innovative work contributed $47.78 \%$ to the investigation composing. The National Cancer Institute's Journal was situated the boss effective magazine of the year with 237 responsibilities. Gupta et al. (2016)12 Scientometric investigated cell breakdown in the lungs in India from 2005-2014 maintained on the Scopus informational collection. The examination investigated distinctive scientometric configuration like most beneficial countries, the land dissemination of the conveyance in India, best makers, most capable journals in India, and tracked down that the verybest 51299 papers contributed by the US, the head dynamic makers were N. Singh and A K Saxena With 37 responsibilities each, CS Prakash with 33 paper responsibilities. 
Lakshmi and Raja (2015)13 Used the catch of science data base to review leukemia research writing in India. Their assessment shows that the overall advancement rate and duplicating time are moving back the example past 2014. This examination uncovered that rectilinear backslide incorporates a- 581088.48 worth. The head beneficial magazine is Annuals of Hematology in Infant Blood and Cancer and thusly the Low Production Magazine whthin the Top 20. The high-repeat expression during this examination is leukemia, and it depicts the best maker, pediatrician Pakshi Sameer with 64 papers.Ayyanar14, et al., did an assessment on Ebola Virus: a scientometric examination of overall conveyance yield 2015-18. A total of 3724 papers were dispersed. The examination responsibility reference impact of the best 10 most helpful countries, the impact of driving overall foundations and makers, perceive the degree of composed exertion and Relative improvement rate and increasing time. Using Web of Science data base. Ayyanar15, et al. done an examination on Norovirus: a scientometric examination of overall conveyance yield 201519. A total of 2683 papers were conveyed. The examination responsibility reference impact of the principle 10 most capable countries, the impact of driving overall establishments and makers, perceive the degree of facilitated exertion and Relative advancement rate and increasing time. Using Web of Science data base

\section{THE OBJECTIVE OF THE STUDY}

$>$ The objective of the assessment:

$>$ To study the maker's clever vehicle of Leukemia Research yield during the year 2010-2019.

$>$ To surveys the level of beginning model and made exertion. for instance Single Vs. Different makers whthin the field of Leukemia Research.

$>$ To survey the improvement of the course of Leukemia Research.

$>$ To see the country-wise spread of Leukemia Research yield.

$>$ To pick the general movement rate and duplicating season capable spread.

$>$ To see the maker's benefit and level of joint exertion with Leukemia Research Publication.

\section{METHODOLOGY}

This assessment has perceived the inspiration driving taking a gander at the Leukemia Research in scientometrics. It similarly subject to the past region of Leukemia Research ships in scientometrics kept up the model data. during this evaluation, data were downloaded from the Web of Science illuminating grouping. The appraisal period was from 2010 to 2019. A total of 6512 records were downloaded and researched by using HistCiteSoftware. Further assessment, MS Excel 2010 and Vos Viewer creating PC programs were wont to research the information to make procedure and designs affiliation understanding.

Data Analysis and Interpretation

TABLE 1

YEAR-WISE DISTRIBUTION OF DOCUMENTS

\begin{tabular}{|c|c|c|c|c|c|c|c|}
\hline S1. No & Year & Records & \% & TLCS & \% & TGCS & \% \\
\hline 1 & 2010 & 489 & 7.51 & 674 & 16.60 & 25174 & 16.07 \\
\hline 2 & 2011 & 598 & 9.18 & 695 & 17.12 & 24403 & 15.57 \\
\hline 3 & 2012 & 618 & 9.49 & 627 & 15.44 & 23508 & 15.00 \\
\hline 4 & 2013 & 603 & 9.26 & 518 & 12.76 & 19200 & 12.25 \\
\hline 5 & 2014 & 602 & 9.24 & 452 & 11.13 & 15765 & 10.06 \\
\hline 6 & 2015 & 654 & 10.04 & 439 & 10.81 & 13721 & 8.76 \\
\hline 7 & 2016 & 698 & 10.72 & 335 & 8.25 & 21092 & 13.46 \\
\hline 8 & 2017 & 756 & 11.61 & 173 & 4.26 & 8451 & 5.39 \\
\hline 9 & 2018 & 756 & 11.61 & 129 & 3.18 & 4483 & 2.86 \\
\hline 10 & 2019 & 738 & 11.33 & 18 & 0.44 & 899 & 0.57 \\
\hline \multicolumn{2}{|c|}{ Total } & 6512 & 100 & 4060 & 100 & 156696 & 100 \\
\hline
\end{tabular}


Table 1 shows the year-wise quantitative movement research yield in the Leukemia Research field in 2010-2019. The most basic number of dispersals in 2017 and 2018 added to 756 scatterings with 11.61\%, the most basic TLCS $17.12 \%$, and TGCS $16.07 \%$. The improvement of the course of action on Leukemia Research continues to make.

TABLE 2

RELATIVE GROWTH RATE AND DOUBLING TIME OF YEAR-WISE DISTRIBUTION

\begin{tabular}{|c|c|c|c|c|c|c|c|}
\hline S1. No & Year & Records & Cumulative & WI & W2 & RGR & DT \\
\hline 1 & 2010 & 489 & 489 & 0 & 6.19 & 6.19 & 0.11 \\
\hline 2 & 2011 & 598 & 1087 & 6.192 & 6.99 & 0.80 & 0.87 \\
\hline 3 & 2012 & 618 & 1705 & 6.394 & 7.44 & 1.05 & 0.66 \\
\hline 4 & 2013 & 603 & 2308 & 6.426 & 7.74 & 1.32 & 0.53 \\
\hline 5 & 2014 & 602 & 2910 & 6.402 & 7.98 & 1.57 & 0.44 \\
\hline 6 & 2015 & 654 & 3564 & 6.400 & 8.18 & 1.78 & 0.39 \\
\hline 7 & 2016 & 698 & 4262 & 6.483 & 8.36 & 1.87 & 0.37 \\
\hline 8 & 2017 & 756 & 5018 & 6.548 & 8.52 & 1.97 & 0.35 \\
\hline 9 & 2018 & 756 & 5774 & 6.628 & 8.66 & 2.03 & 0.34 \\
\hline 10 & 2019 & 738 & 6512 & 6.628 & 8.78 & 2.15 & 0.32 \\
\hline
\end{tabular}

The overall movement rate and duplicating time were settled and the results are tended to in Table 2 . The improvement rate is overall raised in 2010 and the most un-in 2019. This is a drop from Table 2 with relative improvement rates from 2010 (6.19) to 2018 (2.15). The duplicating time (DT) shows an upward model during the evaluation time span. The data from Table 2 uncovers that the duplicating time from 2010 to 2019 is loosening up from 0.11 to 0.32 .

TABLE 3

\section{DEGREE OF COLLABORATION}

\begin{tabular}{|c|c|c|c|c|c|}
\hline S1. No & Year & Single Authored (NS) & Multiple Authored (NM) & Total (NM+NS) & DC \\
\hline 1 & 2010 & 49 & 439 & 488 & 1.11 \\
\hline 2 & 2011 & 51 & 545 & 596 & 1.09 \\
\hline 3 & 2012 & 48 & 568 & 616 & 1.08 \\
\hline 4 & 2013 & 44 & 554 & 598 & 1.08 \\
\hline 5 & 2014 & 36 & 565 & 601 & 1.06 \\
\hline 6 & 2015 & 42 & 610 & 652 & 1.07 \\
\hline 7 & 2016 & 36 & 662 & 698 & 1.05 \\
\hline 8 & 2017 & 35 & 718 & 753 & 1.05 \\
\hline 9 & 2018 & 29 & 753 & 782 & 1.04 \\
\hline 10 & 2019 & 29 & 699 & 728 & 1.04 \\
\hline \multicolumn{2}{|c|}{ Total } & 399 & 6113 & 6512 & 1.07 \\
\hline
\end{tabular}

Table 3 shows the total formation of articles dissipated during the appraisal time period. In this examination, Leukemia Research fuses the degree of joint exertion. To pick the degree of joint exertion concerning entire, the join condition presented by Subramaniam (1983) was used to evaluate collaboration. It shows that the degree of supported exertion goes from zero to 9.244791.

The condition is,

$C=\frac{\mathrm{NM}}{\mathrm{NM}+N S}$

$\mathrm{C}=$ Degree of Collaboration in a discipline or Extent of Collaboration in a discipline 
$\mathrm{NM}=$ Number of Multiple authored papers

NS= Number of Single-authored papers

Here $\mathrm{C}=3384 / 3384+340=0.9087$

TABLE 4

AUTHOR WISE DISTRIBUTION OF PUBLICATIONS (TOP 10)

\begin{tabular}{|c|l|c|c|c|c|}
\hline Sl. No & \multicolumn{1}{|c|}{ Authors } & Records & $\%$ & TLCS & TGCS \\
\hline 1 & Pui CH & 41 & 0.630 & 180 & 2201 \\
\hline 2 & Gale RP & 39 & 0.599 & 59 & 1005 \\
\hline 3 & Lazarus HM & 37 & 0.568 & 50 & 1093 \\
\hline 4 & Saber W & 37 & 0.568 & 50 & 1172 \\
\hline 5 & Lee SJ & 33 & 0.507 & 75 & 1292 \\
\hline 6 & Hudson MM & 32 & 0.491 & 113 & 1348 \\
\hline 7 & Marks DI & 32 & 0.491 & 43 & 917 \\
\hline 8 & Robison LL & 32 & 0.491 & 117 & 1408 \\
\hline 9 & Wang Y & 32 & 0.491 & 10 & 547 \\
\hline 10 & Li J & 30 & 0.461 & 4 & 424 \\
\hline
\end{tabular}

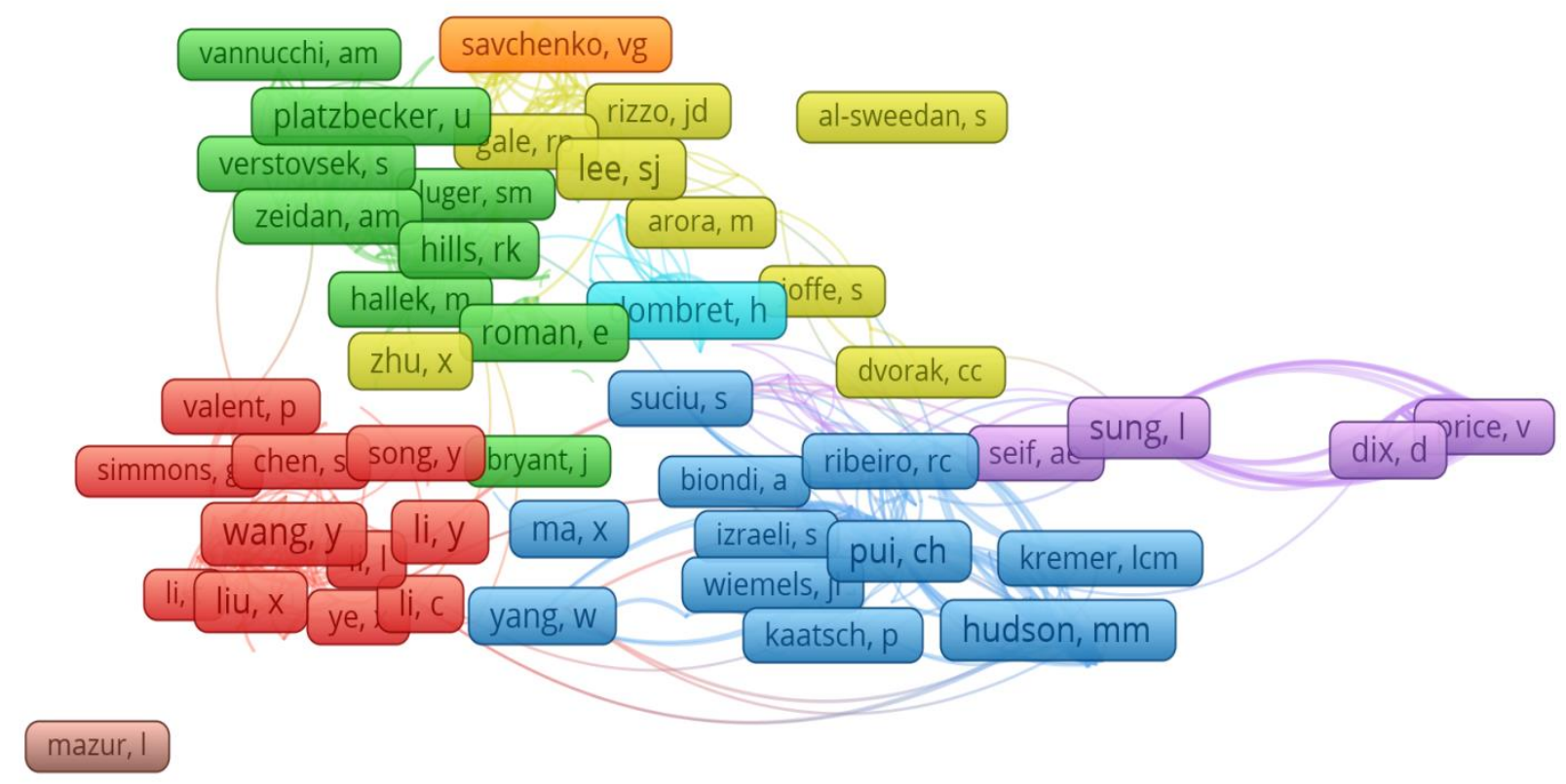

VOSviewer

Figure 1- Author wise Distribution of Research Output

Table 4 shows the improvement of the fundamental 10 makers sharp yields. It might be seen that Pui CH beat the store with $59(0.63 \%)$, followed by second place Gale RP $(0.59 \%)$, Third spot Lazarus HM and Saber W with $37(0.56 \%)$, and Lee SJ with $33(0.50 \%)$, Hudson MM with $32(0.49 \%)$. Li J has last spot with 30 (0.46). 
TABLE 5

\section{AUTHORSHIP PATTERN}

\begin{tabular}{|c|c|c|c|c|c|}
\hline Sl. No & Authors & Contribution & Cumulative & Contribution \% & Cumulative \% \\
\hline 1 & 1 & 399 & 399 & 6.13 & 6.13 \\
\hline 2 & 2 & 888 & 1287 & 13.64 & 19.76 \\
\hline 3 & 3 & 877 & 2164 & 13.47 & 33.23 \\
\hline 4 & 4 & 766 & 2930 & 11.76 & 44.99 \\
\hline 5 & 5 & 663 & 3593 & 10.18 & 55.18 \\
\hline 6 & 6 & 558 & 4151 & 8.57 & 63.74 \\
\hline 7 & 7 & 458 & 4609 & 7.03 & 70.78 \\
\hline 8 & 8 & 368 & 4977 & 5.65 & 76.43 \\
\hline 9 & 9 & 269 & 5246 & 4.13 & 80.56 \\
\hline 10 & 10 & 263 & 5509 & 4.04 & 84.60 \\
\hline 11 & \multicolumn{7}{|l}{ More then 10} & 1003 & 6512 & 15.40 & 100 \\
\hline
\end{tabular}

A basic note of the appraisal is that most of the articles have been presented by second analysts. The single maker contributed $399(6.13 \%)$ papers in this evaluation. The first and second circumstance was more than 10 molded and Second - made; It is settled as $1003(15.40 \%)$ and $888(13.64 \%)$ exclusively. Third makers 'commitments organized third with 877 (13.47\%), and four made position fourth with 766 $(11.76 \%)$. Fifth-made and sixth molded set fifth and sixth, self-rulingly, with $663(10.18 \%)$ and $558(8.57 \%)$. The obligations of the seventh makers and first-made masterminded seventh and eighth with $458(7.03 \%)$, $399(6.13 \%)$ self-sufficiently. The extra eighth makers' obligation is $368(5.65 \%)$ and the ten makers are 263 $(4.04)$

TABLE 6

COUNTRY-WISE DISTRIBUTION OF LEUKEMIA RESEARCH OUTPUT (TOP 10)

\begin{tabular}{|c|l|c|c|c|c|}
\hline S1. No & \multicolumn{1}{|c|}{ Country } & Records & $\%$ & TLCS & TGCS \\
\hline 1 & USA & 2543 & 39.05 & 2242 & 86031 \\
\hline 2 & Peoples R China & 921 & 14.14 & 190 & 13310 \\
\hline 3 & UK & 713 & 10.95 & 1052 & 31239 \\
\hline 4 & Germany & 569 & 8.74 & 518 & 15317 \\
\hline 5 & Italy & 415 & 6.37 & 405 & 12437 \\
\hline 6 & Canada & 398 & 6.11 & 356 & 9544 \\
\hline 7 & France & 382 & 5.87 & 373 & 11058 \\
\hline 8 & Australia & 290 & 4.45 & 192 & 6345 \\
\hline 9 & Netherlands & 270 & 4.15 & 313 & 8510 \\
\hline 10 & Japan & 250 & 3.84 & 185 & 5554 \\
\hline
\end{tabular}




\section{VOSviewer}

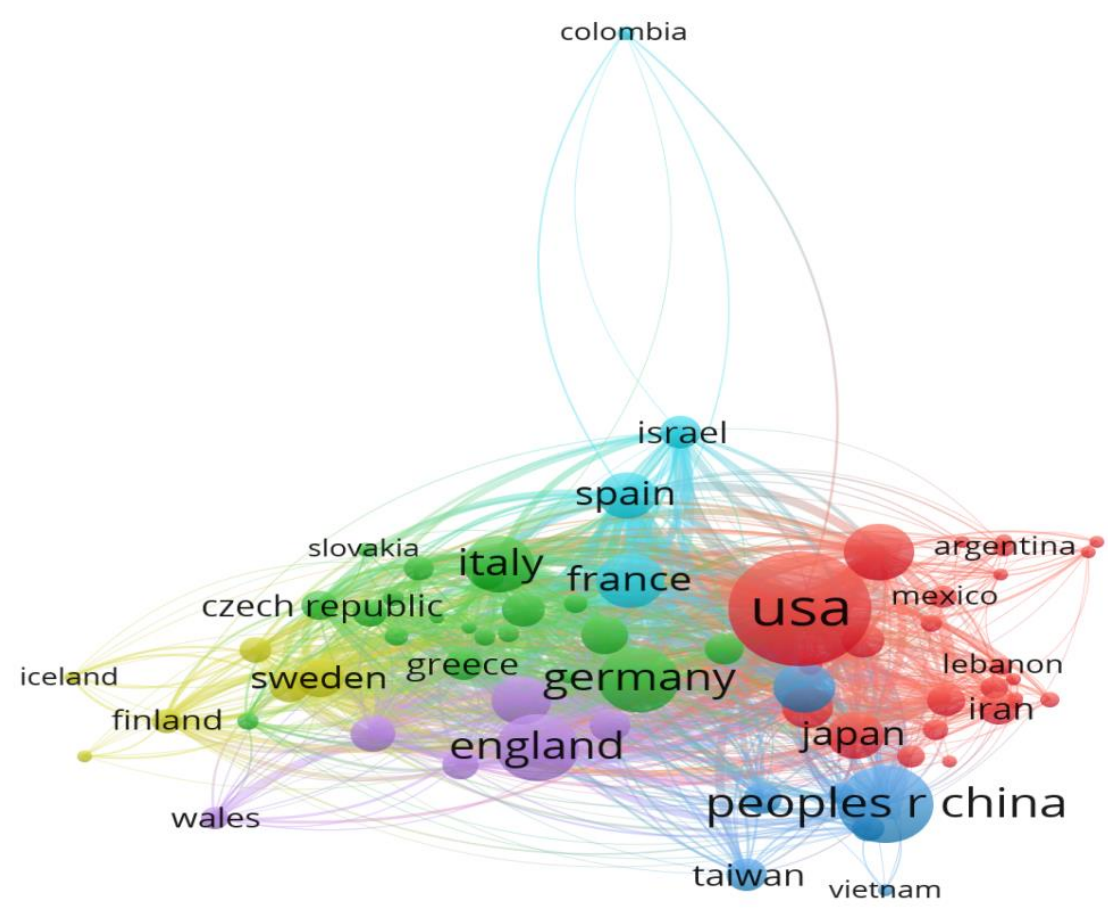

Figure 2- Country wise Distribution of Research Output

The country-wise dispersing of Leukemia research yield is given in table 6 . The USA solidified the most raised situation with 2543(39.05\%) records and China in the second condition with $921(14.14 \%)$. The UK is in the third condition with 713(10.95\%), and other country courses are as per the going with.

TABLE 7

\section{DOCUMENT WISE DISTRIBUTION OF ARTICLES}

\begin{tabular}{|c|l|c|c|c|c|}
\hline S1. No & \multicolumn{1}{|c|}{ Document Type } & Records & $\mathbf{\%}$ & TLCS & TGCS \\
\hline 1 & Article & 4035 & 61.96 & 2798 & 93486 \\
\hline 2 & Review & 2072 & 31.82 & 1156 & 58658 \\
\hline 3 & Editorial Material & 114 & 1.75 & 49 & 821 \\
\hline 4 & Meeting Abstract & 86 & 1.32 & 0 & 78 \\
\hline 5 & Article; Proceedings Paper & 60 & 0.92 & 14 & 731 \\
\hline 6 & Review; Book Chapter & 41 & 0.63 & 24 & 2333 \\
\hline 7 & Article; Book Chapter & 39 & 0.60 & 12 & 479 \\
\hline 8 & Article; Early Access & 27 & 0.41 & 0 & 5 \\
\hline 9 & Letter & 20 & 0.31 & 6 & 94 \\
\hline 10 & Review; Early Access & 8 & 0.12 & 0 & 1 \\
\hline
\end{tabular}

Table 7 shows the report sharp arrangement of scatterings. Articles cover the most favored sort is 4035(61.96\%) as Review, 2072(31.82\%) as Editorial Material and other scattering followed by different developments. 
TABLE 8

TOP RANKED INSTITUTION AND PERCENT (TOP 10)

\begin{tabular}{|c|l|c|c|c|c|}
\hline S1. No & \multicolumn{1}{|c|}{ Institution } & Records & \% & TLCS & TGCS \\
\hline 1 & University Texas MD Anderson CancerCtr & 212 & 3.26 & 285 & 7742 \\
\hline 2 & Mayo Clin & 151 & 2.32 & 157 & 4542 \\
\hline 3 & University Minnesota & 146 & 2.24 & 246 & 5116 \\
\hline 4 & Dana Farber CancInst & 140 & 2.15 & 219 & 5392 \\
\hline 5 & NCI & 139 & 2.13 & 257 & 6604 \\
\hline 6 & Fred Hutchinson Cancer Res Ctr & 134 & 2.06 & 254 & 4912 \\
\hline 7 & St Jude Children's Res Hosp & 134 & 2.06 & 351 & 5239 \\
\hline 8 & Mem Sloan Kettering CancerCtr & 117 & 1.80 & 176 & 3912 \\
\hline 9 & Med Coll Wisconsin & 116 & 1.78 & 159 & 3514 \\
\hline 10 & University Penn & 102 & 1.57 & 93 & 3193 \\
\hline
\end{tabular}

univ alberta hosp

childrens hosp eastern ontario

bc childrens hosp

hosp sick children

dalhousje univ royal prince alfred hosp univ dundee

univ british columbia

sa pathol

castle hill hosp

fred hutchinson cancres ctr

univ coll london hosp

ucl gazi univ

univ texas md anderson canc ct

taipei med univ harvard med sch niaid univ ulm inserm univlyon

china med univ

sichuan univ

tehran chinese acad sci

VOSviewer binzhou med univ

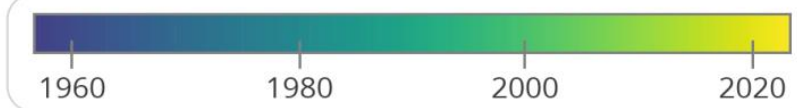

Figure 3 - Institution-wise Distribution of Research Output

This table presents alliance vigilant evaluation productivity. It's unmistakable that the University Texas MD Anderson CancerCtr positions first position so as in by contributing 212(3.26) record scatterings Mayo Clinrecords the second condition with 151(2.32) record tasks. School Minnesota records the third situation with 146(2.24) record scatterings. The progressions of various Institutions are according to the going with. 
TABLE 9

JOURNAL WISE DISTRIBUTION OF PUBLICATIONS (TOP 10)

\begin{tabular}{|c|l|c|c|c|c|}
\hline Sl. No & Name of the Journal & Records & \% & TLCS & TGCS \\
\hline 1 & Blood & 130 & 2.00 & 332 & 7727 \\
\hline 2 & Pediatric Blood \& Cancer & 117 & 1.80 & 136 & 1569 \\
\hline 3 & Biology of Blood and Marrow Transplantation & 101 & 1.55 & 125 & 2158 \\
\hline 4 & British Journal of Cancer & 97 & 1.49 & 176 & 5145 \\
\hline 5 & Plos One & 94 & 1.44 & 0 & 1725 \\
\hline 6 & Journal of Clinical Oncology & 75 & 1.15 & 433 & 6890 \\
\hline 7 & British Journal of Haematology & 64 & 0.98 & 72 & 1230 \\
\hline 8 & Leukemia \& Lymphoma & 64 & 0.98 & 28 & 547 \\
\hline 9 & Radiation Research & 64 & 0.98 & 75 & 1600 \\
\hline 10 & Cancer & 56 & 0.86 & 56 & 1014 \\
\hline
\end{tabular}

\section{current opinion in hematology \\ expert opinion on investigatio

$$
\text { expert review of hematology }
$$

experimental hematology

$$
\text { epigenetics blood }
$$

journal of hematology \& oncolo leukemia blood cancer journal

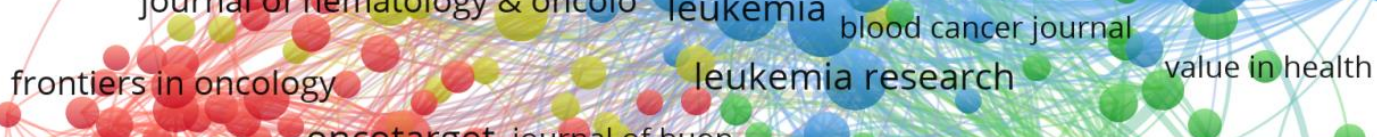

oncotarget journal of buon

\section{expertopinion on biologicalt}

journal of clinical oncology clinical infectioi

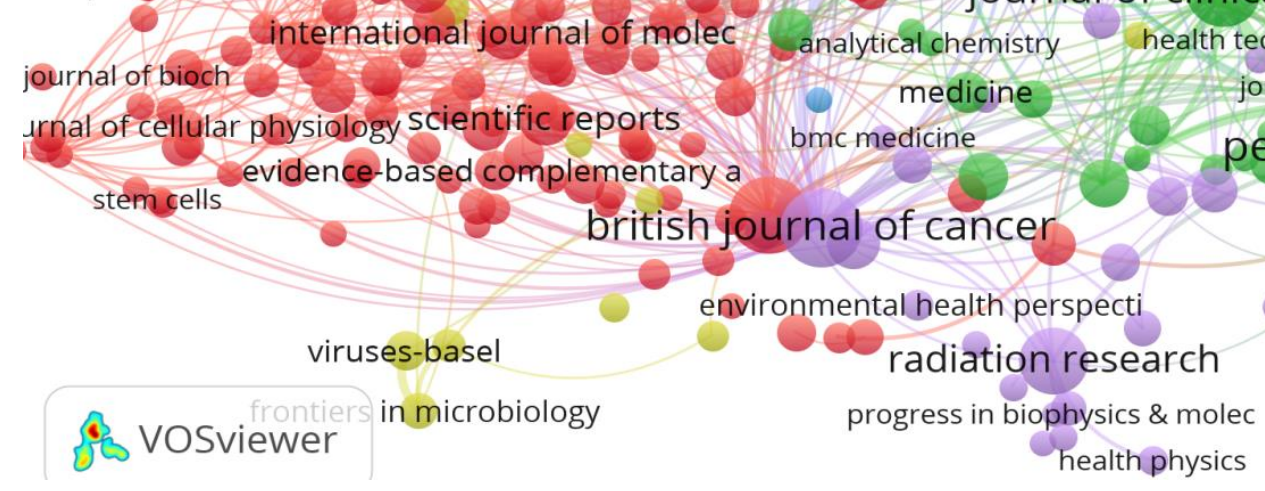

Figure 4- Journal wise Distribution of Research Output

Table 9 shows the Journal sharp course of action of developments in Leukemia research. The journal Bloodrecords the essential condition with $130(2.00 \%)$. The ensuing position is joined by is that the Pediatric Blood and Cancer with 117(1.80\%). The records of various journals are as shown by the going with. 
TABLE 10

KEY WORD-WISE DISTRIBUTION OF PUBLICATIONS (TOP 10)

\begin{tabular}{|c|c|c|c|c|c|}
\hline Sl. No & Words & Records & $\%$ & TLCS & TGCS \\
\hline 1 & Leukemia & 1480 & 22.73 & 1439 & 23422 \\
\hline 2 & Cancer & 1436 & 22.05 & 979 & 56262 \\
\hline 3 & Cell & 945 & 14.51 & 607 & 21318 \\
\hline 4 & Acute & 892 & 13.70 & 1087 & 15763 \\
\hline 5 & Cells & 688 & 10.57 & 237 & 14574 \\
\hline 6 & Patients & 598 & 9.18 & 625 & 11999 \\
\hline 7 & Myeloid & 583 & 8.95 & 621 & 9772 \\
\hline 8 & Research & 556 & 8.54 & 484 & 11404 \\
\hline 9 & Stem & 475 & 7.29 & 325 & 13467 \\
\hline 10 & Chronic & 445 & 6.83 & 343 & 6404 \\
\hline
\end{tabular}

Table 10 discussed the watchword cunning errand of spreads. The high-reiterate watchword glancing through piece of Leukemia research inside the stream examination is Leukemia1480 $(22.73 \%)$, and various explanations were Cancer $1436(22.73 \%)$ as Patients and various streams followed by various plans.

\section{CONCLUSION}

The evaluation wrapped up about the Leukemia research, it's speculated that the assessment advantage on Laryngeal Cancer research uncovers a reformist unexpected turn of events and generally assessment during the year 2010-2019 was picked to look the scientometric revolve around Leukemia research. To lead the above evaluation, the data were accumulated from the catch of science. Levelheaded quantitative instruments and framework were utilized this assessment. Following to get-together data and applying genuine instruments and strategies, the results were presented inside such a tables for better technique. A proportion of 6512 records were amassed from the Leukemia research informative variety for the evaluation through looking with the explanation Leukemia 1480(22.73\%), and various watchwords being Cancer. The Author-wise movement of the dispersing showed that the Pui $\mathrm{CH}$ joined the basic condition with portions $41(0.63 \%)$ and Gale RP is in the second circumstance with $39(0.59 \%)$ followed by Lazarus HW, Saber W, et al. moreover, others. Li J consolidated the last condition with 30 dispersals $(0.46 \%)$. The year-wise scattering of records in Leukemia Research revealed that the year 2017 and 2018 consolidated the standard position and thusly the yield was expanded (11.61\%). All through late different years, defilement research has filled in size and impact. Clinicians, examiners, and government and state policymakers have kept up difficulty research, from studies to see low-tech, gigantic extension achievement results to a the highest point of the most amazing regions of head subverting headway science.

This article has been made with the money related assistance of RUSA - Phase 2.0grant maintained vide Letter No. F.24-51/2014-U, Policy (TNMulti-Gen),

Dept. of Edn. Govt. of India, Dt.09.10.2018 


\section{REFERENCES}

1. Swerdlow SH, Campo E, Harris NL, Jaffe ES, Pileri SA, Stein H, et al., editors. WHO plan of tumors of hematopoietic and lymphoid tissues. fourth ed. Geneva: World Health Organization; Lyon: IARC Press, 2008

2. Bennett, J.M., Catovsky, D., Daniel, M.T., Flandrin, G., Galton, D.A.G., Gralnick, H.R. moreover, Sultan, C. (1982) "Proposals for the social event of the myelodysplastic issue", British Journal of Hematology, 51, 189 - 199.

3. Germing, U., Gattermann, N., Minning, H., Heyll, A. moreover, Aul, C. (1998) "Problems in the solicitation for CMML. Dysplastic versus proliferative sort", Leukemia Research, 22, 871 - 878.

4. Michaux, J.L. plus, Martiat, P. (1993) "Chronicmyelomonocyticleukaemia (CMML). A myelodysplastic or myeloproliferative syndrome?", Leukemia and Lymphoma, 9, 35 - 41.

5. Leikin SL. Past proforma assent for youth disorder research. J Clin Oncol 1985;3:420-8.

6. Thomasma DC, Mauer AM. Moral intricacies of clinical helpful examination on kids. SocSci Med 1982;16:913-9.

7. Levi R, Marsick R, Drotar D, Kodish ED. Finding, receptiveness, and educated assent: obtaining from guards of youngsters with perilous turn of events. J PediatrHematolOncol 2000;22:3-12.

8. Flores G. Culture and the patient-expert relationship: Achieving social competency in clinical thought. J Pediatr 2000; 136:14-23.

9. DELORES, and C. BORWMANO1. 928. Leucbmieaigue au cours de I'intoxicationbenzenique: surl'originetoxique de certainesleudmiesaigues et leur relations avec les ankmies graves. J. Medications. Lyon 9: 227.

10. IARC Monographs on the Evaluation of Cancerogenic Risk of Chemicals in Man. 1974. Vol. 7: 203. IARC. Lyon, France.

11. Jeyshankar, R., and Babu, B. R. (2013). Scientometric evaluation of leukemia research yield (19602011): An Indian viewpoint. Asia Pacific Journal of Library and Information Science. Vol, 3(2).

12. Gupta, R., Ahmed, K. M., Gupta, B. M., \&Bansal, M. (2016). Cell breakdown in the lungs in India: A scientometric assessment of dispersals during 2005-14. Generally Journal of Medicine and Public Health, 6(4).

13. Lakshmi, M., and Raja, S. (2015). Leukemia research writing in India: a scientometric evaluation. Diary of Advances in Library and Information Science, 4(2), 182-186.

14. Ayyanar, K., Alagu, A., \&Clarance, M. M.(2020). Scientometric Analysis of Ebola Virus Research yield: A Global Perspective.Journal of Xidian University, 14(4), 1101-1111. doi.org/10.37896/jxu14.4/130

15. Ayyanar, K., Mercy Clarance, M., \&Alagu, A.(2020). Improvement and Authorship Pattern of Norovirus Research Output: A Scientometric Study. Handbook of Metric Studies for Library and Information Science Scholars, ISBN:978-81-944843-6-3, 70-81. 